\title{
Lexis
}

Journal in English Lexicology

15 | 2020

The adjective category in English

\section{Feeling, emotion and the company they keep: what adjectives reveal about the substantives feeling and emotion}

Stéphanie Béligon

\section{(2) OpenEdition \\ Journals}

Electronic version

URL: http://journals.openedition.org/lexis/4322

DOI: $10.4000 /$ lexis.4322

ISSN: 1951-6215

Publisher

Université Jean Moulin - Lyon 3

\section{Electronic reference}

Stéphanie Béligon, «Feeling, emotion and the company they keep: what adjectives reveal about the substantives feeling and emotion », Lexis [Online], 15 | 2020, Online since 13 June 2020, connection on 17 December 2020. URL : http://journals.openedition.org/lexis/4322 ; DOI : https://doi.org/10.4000/ lexis. 4322

This text was automatically generated on 17 December 2020.

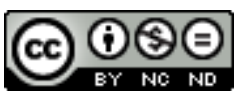

Lexis is licensed under a Creative Commons Attribution-NonCommercial-NoDerivatives 4.0 International License. 


\title{
Feeling, emotion and the company they keep: what adjectives reveal about the substantives feeling and emotion
}

\author{
Stéphanie Béligon
}

\section{Introduction}

1 The substantives feeling and emotion have very similar meanings in contemporary English in some of their uses: the Oxford English Dictionary (OED), for instance, defines emotion as "any strong mental or instinctive feeling, as pleasure, grief, hope, fear, etc., deriving esp. from one's circumstances, mood, or relationship with others" and feeling as "[ $t$ ]he condition of being emotionally affected or committed; emotion, sentiment; an instance of this, an emotion (of hope, joy, sorrow, etc.)" ${ }^{1}$. The two lexical items are therefore considered to be synonymous, since they are used to define each other.

2 This contribution argues that such a view is misleading, and that even when feeling and emotion refer to affects, they are not semantic equivalents, as they designate different types of affects: emotion refers to pre-semantic experience, in the sense that the experience it denotes has not been given a meaning yet, whereas feeling designates categorized affects. To defend this hypothesis, which is backed up by Barrett [2006]'s findings in neuroscience about core affect and emotions, this paper analyzes the collocations formed by the two nouns, and more specifically the sequences ADJECTIVE emotion(s) and ADJECTIVE feeling(s). It focuses on British and American English and is based on data collected from the Corpus of Contemporary American English (COCA) and the British National Corpus (BNC).

3 The first section takes stock of the debates about the meaning of the two substantives; the second deals with the collocations formed by emotion and feeling in the singular; the third section presents Barrett's theory of core affect and emotions and shows its 
relevance in the study of the meaning of emotion and feeling; the fourth section highlights the connection between the semantic characteristics of the nouns and their semantics. Finally, the fifth and last section offers a few remarks about the plurals feelings and emotions and the adjectives they co-occur with.

\section{State of the question}

\subsection{Definitions}

4 The two definitions the OED provides of emotion in its current use ("any strong mental or instinctive feeling, as pleasure, grief, hope, fear, etc., deriving esp. from one's circumstances, mood, or relationship with others" and "[a]s a mass noun: strong feelings, passion; (more generally) instinctive feeling as distinguished from reasoning or knowledge") show that according to the dictionary, emotion designates a strong and irrational feeling.

5 Feeling is in its turn given definitions quite similar to those of emotion: "The condition of being emotionally affected or committed; emotion, sentiment; an instance of this, an emotion (of hope, joy, sorrow, etc." - "He'd forgotten the sad gray feeling that had settled on him lately") $)^{2}$. The circularity of these definitions does not make it easy to grasp the exact meaning of emotion and feeling.

$6 \quad$ Feeling has other definitions, some related to sensations ("A physical sensation or perception (as of touch, heat, cold, pain, motion, etc.) experienced through this capacity" - "A lack of potassium in your system can cause feelings of nausea"), to opinions ("An idea, belief, or sense (especially a vague or irrational one) that a particular thing is true; an impression that something is about to happen or is the case; an intuition about something" - "I have a funny feeling you'll be back"), to talent "A talent or aptitude; an affinity or intuitive understanding" - "He said they had a 'feeling' for how materials worked, a feeling for brittleness, strength and workability" or to the effect produced by what is perceived ("The quality or condition which is felt to belong to anything; the general impression or effect produced on a person by an object, a place, another person, etc." - "This charming West Village spot evokes the feeling of a Parisian bistro à vins"). Feeling has therefore multiple meanings which, as we shall see in Section 2, are often intertwined.

7 These definitions leave two questions unanswered: how do emotion and feeling differ when they refer to affects? How are the several meanings of feeling related to one another? As we shall see in the next subsection, the various studies devoted to these issues do not provide very clear answers either.

\subsection{Wierzbicka [1999]}

8 Wierzbicka [1999] points out that several scientific traditions equate emotions with purely physiological reactions in the wake of behaviourism ${ }^{3}$; the opposite stance, represented by authors such as Solomon [2007], considers them to be judgments and reduce feelings to bodily feelings. Wierzbicka [1999: 2] thinks that emotion has a more complex meaning than feeling:

The English word emotion combines in its meaning a reference to "feeling", a reference to "thinking", and a reference to a person's body. For example, one can 
talk about a "feeling of hunger", or a "feeling of heartburn", but not about an "emotion of heartburn", because the feelings in question are not thought-related. One can also talk about a "feeling of loneliness" or a "feeling of alienation", but not an "emotion of loneliness" or an "emotion of alienation", because while these feelings are clearly related to thoughts (such as "I am all alone", "I don't belong" etc.), they do not suggest any associated bodily events or processes (such as rising blood pressure, a rush of blood to the head, tears, and so on).

9 She also rejects the view that feeling designates purely bodily feeling: "[...] I do not agree that "feelings" equals "bodily feelings". For example, if one says that one feels "abandoned", or "lost", one is referring to a feeling without referring to anything that happens in the body" (Wierzbicka [1999:2]), however she does not provide any definition of feeling, as she considers that feel is a semantic prime, which, as such, cannot be broken down into several semantic components.

Her account underlines the discrepancy between the meaning of the word emotion in common parlance and its use in some scientific fields, and makes it clear that this use is imbued with theoretical biases. However, her own comparison of emotion and feeling remains sketchy.

\subsection{Damasio [1994]}

11 Damasio [1994: 139] also opposes emotion and feeling:

I see the essence of emotion as the collection of changes in body state that are induced in myriad organs by nerve cell terminals, under the control of a dedicated brain system, which is responding to the content of thoughts relative to a particular entity or event.

Here again, an emotion is described as consisting of a series of physiological reactions, whereas feelings are reflexive:

A feeling in essence is an idea - an idea of the body and, even more particularly, an idea of a certain aspect of the body, its interior, in certain circumstances. A feeling of emotion is an idea of the body when it is perturbed by the emoting process. [Damasio 2003: 88].

In this view, feelings follow from emotions and are complex representations of both the changes undergone by the body and what causes these changes. Contrary to Wierzbicka's stance, feelings are seen as more complex than emotions.

Once again, one may wonder whether these definitions are in keeping with common parlance.

This brief overview shows that the exact connection between the meanings of feeling and emotion is not straightforward and that scholars do not all designate the same phenomena by means of those words.

Hilgert [2018: 81], who analyzes the semantics of the French noun émotion, also notes a gap between scientific use and common parlance in French:

Il y a plutôt une polysémie installée entre la langue de spécialité, où le $\mathrm{N}$ émotion est générique d'un ensemble de types d'émotions et regroupe peur, tristesse, colère, etc., qui lui sont subordonnés, et l'usage commun, où le nom émotion désigne une manifestation spécifique du même niveau que peur, colère, tristesse, etc. [...] se plaçant au même niveau lexical que ces derniers. ${ }^{4}$ 
The author states that the study of the modifiers of émotion can clarify the meaning of the noun (cf. Hilgert [2018: 81]). The approach adopted here follows the same principle and focuses on adjectives.

\section{Study of the adjectives co-occurring with emotion and feeling}

\subsection{Why study adjectives?}

This paper concentrates on adjectives on the grounds set out by Cotte [1997: 68], who explains that "le nom est synthétique, il occulte la complexité du référent", whereas an adjective "est analytique et il se charge de dévoiler et d'expliciter les qualités contingentes que le nom néglige ou celles qu'il recèle dans sa définition synthétique"5:

Ainsi, le nom unique synthétise les traits jugés structurels qui identifient le référent

à un type stable préconstruit, alors qu'un ou plusieurs adjectifs analysent les propriétés, contingentes ou non, à mesure que l'énonciateur les dévoilent et s'il le souhaite. L'adjectif sépare, égrène, explicite, il met au jour ce que le nom met au secret ; il exprime aussi des évaluations concernant le référent. ${ }^{6}$

Adjectives are therefore likely to shed light on the nature of what is designated by feeling and emotion, and to illustrate how the two nouns differ in their meaning.

\subsection{ADJECTIVE emotion}

The substantive emotion occurs 9919 times in the COCA in its singular form, and there are 639 types of sequences ADJECTIVE emotion; 55 adjectives occur more than 5 times in the corpus in that sequence, as shown in Table $1^{7}$ :

Table 1: Adjectives occurring more than 5 times in the sequence ADJECTIVE emotion (COCA)

\begin{tabular}{|l|l|l|l|l|}
\hline human (128) & powerful (29) & heightened (13) & complex (7) & excessive (6) \\
raw (101) & pure (27) & religious (13) & big (7) & experienced (6) \\
strong (63) & different (21) & pent-up (12) & extreme (7) & individual (6) \\
negative (57) & new (21) & strange (10) & heartfelt (7) & inner (6) \\
real (57) & only (21) & honest (9) & moral (7) & mixed (6) \\
deep (52) & high (19) & main (9) & outward (7) & prevailing (6) \\
intense (49) & particular (19) & suppressed (9) & public (7) & sheer (6) \\
great (44) & dominant (17) & sweet (9) & sudden (7) & sincere (6) \\
genuine (31) & overwhelming (16) & basic (8) & actual (6) & underlying (6) \\
other (30) & personal (15) & primary (8) & aesthetic (6) & unfamiliar (6) \\
positive (29) & true (15) & strongest (8) & evident (6) & useless (6) \\
\hline
\end{tabular}

In the $B N C$, which is a smaller corpus than the $C O C A^{8}$, the number of occurrences of emotion (1 464 occurrences in the singular) and of sequences ADJECTIVE emotion is more limited (197 types of sequences); this is why the query includes combinations that occur at least three times (and not five, as was the case with the COCA). One of the advantages of the $B N C$ is to indicate the log-likelihood value of the collocations, and the 
adjectives are ordered according to that value in Table 2 (as in Table 4, 6 and 8). The query yields 24 adjectives and there is a large overlap between the lexemes found in the two corpora.

Table 2: Adjectives occurring at least 3 times in the sequence ADJECTIVE emotion (BNC)

\begin{tabular}{|l|l|}
\hline suppressed (7) & real (7) \\
expressed (7) & raw (4) \\
human (14) & violent (4) \\
intense (9) & strongest (3) \\
strong (13) & excessive (3) \\
pent-up (5) & religious (4) \\
powerful (9) & naked (3) \\
overwhelming (6) & sensitive (3) \\
profound (5) & high (5) \\
deep (7) & positive (3) \\
dominant (5) & great (3) \\
heightened (3) & new (4) \\
\hline
\end{tabular}

Several semantic fields can be identified:

- category A: most of these adjectives are connected with intensity: deep, excessive, great, heightened, (heartfelt), high, intense, overwhelming, powerful, raw, (sheer), strong';

- category B: some are related to the manifestations - or the lack thereof - of the emotion they characterize: (evident), (expressed), (genuine), (honest), (outward), pent-up, real, sincere, suppressed;

- other adjectives are classifying adjectives: (aesthetic), (moral), (negative), positive, religious.

These semantic tendencies reflect the way affects designated by emotion are conceptualized. Intensity adjectives, such as deep, great, strong or powerful, do not give any indication about the nature of what is felt, as shown in the following examples:

(1) William Bartram's meticulous descriptions are more than just scientific observation; his book is considered an American classic by scholars. He wrote about the environment with great emotion, and he influenced many Romantic-era European poets and literary figures. They were fascinated with his sensitive observations of Native Americans and with his poetic descriptions of nature. (COCA, Martha M. Ezzard, "Follow Trail of $18^{\text {th }}$ century Explorer", Atlanta Journal Constitution, 2006) ${ }^{10}$

(2) The widening of the franchise in the nineteenth century, House of Lords reform, and votes for women in the twentieth - these are issues that aroused great emotion and were fiercely opposed but on which reform was accepted once the government of the day had got the measure accepted by Parliament. (BNC, Philip Norton, The British Polity, 1984)

(3) Prof WILSON: It seems to me that when you feel deep emotion, you're having a really intense experience of one kind of another.

ANNE: Right.

Prof WILSON: Sometimes, sorrows attach to it, sometimes joy is attached to it. And once you'd be able to express that fully, that, in my mind, leads to an 
authentic existence. (COCA, "Happiness Is Overrated", Talk of the Nation, NPR, 2008)

Examples (1) and (2) feature the sequence great emotion, but it does not refer to the same kind of affect in both cases: in (1), the phrase is associated with admiration and sympathy, whereas it is connected with indignation and opposition in (2). In example (3), the speaker underlines that deep emotion can refer to an affect having negative (sorrows) or positive valence (joy).

Emotion can also refer to an affect that is out of control, as shown by the phrases "barely held in check" and "overwhelmed" in examples (4) and (5):

(4) Her expression changed again, and anger replaced the misery I thought I'd detected just a few seconds before. "I wouldn't know. That photo and these old letters are all I have to go on." She laid a bundle of envelopes on the desk beside the genealogical chart.

I had no idea where this was going, but I could sense some deep emotion barely held in check. (COCA, Kathryn R. Wall, Covenant Hall: a Bay Tanner Mystery, 2009)

(5) In 2002, Halle Berry became the first woman of color to win a Best Actress Oscar, and while she highlighted the historic and political significance of the moment, her speech is best remembered for its raw emotion. After taking the stage, Berry was so overwhelmed, she struggled to stay composed, finally collecting her thoughts enough to dedicate the award to groundbreaking women like Dorothy Dandridge, Lena Horne, and Diahann Carroll. (COCA, "The Long History of Oscar Speeches as Political Protest", The Verge, 2017)

As Romero [2004: 451-452] points out, it is possible to distinguish between several categories among intensity adjectives. She notes that:

[...] ce que fait l'adjectif intensif, c'est situer l'occurrence en haut de l'échelle qui définit le nom. Énorme dans énorme envie ou terrible dans chaleur terrible ne qualifient pas tant l'envie ou la chaleur (comme le feraient envie bizarre, ou chaleur humide), et ne les rangent pas tant dans une classe (les envies énormes ne constituent pas un type d'envie comme les envies de voyage), qu'ils ne signifient que l'on se situe en haut de l'échelle de "envie" ou de "chaleur". ${ }^{1112}$

However, she observes that there is a thin line between descriptive adjectives and intensity adjectives:

Comme il ne s'agit que d'emploi intensif et d'emploi qualificatif intense, mais que cela concerne au fond les mêmes adjectifs, la séparation entre ces deux types de syntagmes n'est pas toujours bien nette. De fait, les adjectifs intensifs peuvent souvent être intenses par ailleurs. Donc, entre le qualificatif intense eau bouillante et l'intensif pur énorme envie, extrême bonté (où l'adjectif ne fait qu'intensifier), on trouve échec cuisant, banalité consternante, amour passionnel où il y a à la fois intensification (quelque chose qui est d'une banalité consternante est d'“une grande banalité" ou "très banal") et qualification (consternant = "qui est propre à consterner", malgré l'éventuelle hyperbole). ${ }^{13}$

She differentiates between pure intensity adjectives, which are directly intensive:

Par exemple, haut intérêt est un intensif direct car, à partir du sens qualificatif de haut, on n'a pas de calcul interprétatif particulier à faire pour situer l'occurrence en haut de l'échelle "intérêt" (c'est-à-dire pour interpréter "très intéressant") ${ }^{14}$ [Romero 2004: 455].

and descriptive adjectives that refer to intensity indirectly:

Les adjectifs intensifs contenant une part de qualification sont intensifs après inférence. Par exemple, pour interpréter banalité consternante, on doit faire un petit 
calcul interprétatif du genre : 'Sachant que seul ce qui est très banal peut provoquer

la consternation, ceci est donc très banal' ${ }^{15}$ [Romero 2004: 455]. honest, outward, pent-up, real, sincere or suppressed - refer to how and whether an emotion is manifested. It is possible to divide that category into two: some of those lexemes refer to whether or not the emotion is visible or expressed (evident, outward, pent-up, suppressed) and others to the equation between the affect displayed and what is actually felt by the experiencer (genuine, honest, real, sincere):

(6) "Marvin," I said, kneeling beside the chair to look him in the eyes," "you're 6 years old now, and 6-year-olds go to big schools. Today is the last day you will be here with us. Tomorrow morning a big bus will come to take you to the first grade. I'm very proud of you."

I looked for even the slightest flicker of regret or sadness, but he showed no outward emotion. (COCA, Dorothy Olhaver, "Expecting More than Stillbirth", Houston Chronicle, 1992)

(7) Almost all children have tantrums, and they start having them at about the same age - somewhere between 20-30 months. [...] A tantrum is a sudden release of pent-up emotion, a mixture of rage, frustration and anger. (BNC, Parents, 1991)

The semantics of these adjectives, as well as the meaning of the utterances ("he showed no sign of outward emotion", "His face was white with suppressed emotion") show that an emotion is conceived of as a phenomenon that is intrinsically visible or has outward manifestations: its "release" (cf. example (7)) goes hand in hand with its becoming visible, which is in keeping with the etymology of the word ${ }^{16}$. Consequently, what is shown can correspond to what is felt by the experiencer or not, hence the use of adjectives such as actual, genuine, honest, real or sincere:

(8) Spitzer moved quickly to meet with the media, and he was brief and to the point. He had "begun to atone for his private failings," he said, but he recognized his betrayal of the public. [...] His wife's demeanor, described by the press as "ashen-faced" and "stricken," provided a shocking display of genuine emotion in the midst of the predictable ceremony. (COCA, Kay S. Hymowitz, "The National Adultery Ritual", Commentary, 2011)

(9) "No matter what you think of me," she said, "all these months I have truly had your best interest in mind. I thought I was doing what was right." Medicine Wolf lowered the knife, seeing for the first time in nearly two years a hint of sincere emotion in the woman's eyes." (COCA, Rosanne Bittner, Song of the Wolf, 1992) 
30 mentioned: in examples (8) and (9), the emotion is considered to be genuine or sincere because it is visible.

31

Category B adjectives thus suggest that emotions are intrinsically visible, even when the experiencer tries to hide or control them (cf. pent-up and suppressed).

Category $\mathrm{C}$ consists of classifying adjectives, some of which have to do with the very nature of the emotion characterized (aesthetic, moral, religious) and others with its valence (negative, positive):

(10) Summing up his own aesthetic, he writes, "This relief that brings the sense of power, and, with the sense of power, joy, is the positive emotion which tells us that we have encountered a first-rate piece of literature. (COCA, Lewis M. Dabney, "The Shy Little Scholar of Holder Court", American Scholar, 1990) (11) Conversely what we call aesthetic emotion is trivialized if we take it as only a reaction to the power of form. I think aesthetic emotion is a condition of will that accompanies our regarding the work as offering a distinctive and powerful state of mind. Aesthetic emotion may even be considered a strange kind of affect because it tends not to be focussed on any particulars within the work but to characterize the force by which we respond to the piece as a whole, as if we were willing to take responsibility for who we became by virtue of our participation in it. (COCA, Charles Altieri, "Lyrical Ethics and Literary Experience", Style, 1998)

Category $\mathrm{C}$ is therefore made up of adjectives that leave the particular feel of the affect opaque: adjectives referring to its valence divide the experience into very broad categories, whereas those linked with the field it belongs to (aesthetic, moral, religious) do not give any indication about the actual experience of the emotion.

This overview of the attributive adjectives modifying emotion highlights the fact that the affects designated by emotion remain opaque, which is in keeping with the use of emotion as a mass noun in the majority of the utterances quoted above: if emotion refers to a powerful, shapeless phenomenon, it is reminiscent of the definition given by Langacker [1990: 69] of a mass noun, which "designates a region that is NOT specifically bounded within the scope of predication in its primary domain" ${ }^{17}$.

As we shall see in the next subsection, the adjectives modifying feeling form a different pattern.

\subsection{ADJECTIVE feeling}

\subsubsection{Semantic categories}

The substantive feeling is more frequent than emotion in the COCA (35 485 occurrences in the corpus) and there are over 1800 types of sequences ADJECTIVE feeling; the 97 adjectives occurring more than 15 times in the corpus are indicated in Table 3: 
Table 3: Adjectives occurring in the sequence ADJECTIVE feeling (COCA)

\begin{tabular}{|l|l|l|l|}
\hline good (614) & overwhelming (71) & tremendous (38) & \\
bad (365) & weird (70) & similar (37) & unpleasant (24) \\
great (363) & growing (69) & negative (36) & peaceful (23) \\
strong (295) & awful (67) & common (35) & whole (23) \\
general (226) & better (67) & cold (34) & constant (21) \\
strange (188) & deep (67) & comfortable (34) & unbelievable (21) \\
sick (148) & overall (65) & helpless (34) & particular (20) \\
uneasy (135) & widespread (63) & powerful (34) & profound (20) \\
warm (135) & human (61) & sudden (34) & unsettling (20) \\
wonderful (128) & horrible (60) & emotional (33) & heady (19) \\
funny (126) & nagging (60) & greatest (33) & lonely (19) \\
different (120) & vague (55) & strangest (33) & peculiar (19) \\
real (108) & certain (51) & happy (32) & busy (18) \\
odd (104) & incredible (50) & greater (31) & curious (18) \\
eerie (98) & positive (48) & pleasant (31) & extraordinary (18) \\
personal (86) & queasy (46) & scary (29) & guilty (18) \\
terrible (85) & religious (46) & true (29) & panicky (18) \\
new (82) & familiar (44) & anti-American (28) & public (18) \\
best (81) & worst (44) & natural (28) & strongest (18) \\
special (77) & creepy (43) & hollow (25) & comforting (17) \\
nice (75) & other (25) & inner (17) \\
amazing (74) & intense (41) & awesome (24) & satisfying (17) \\
distinct (74) & sickening (41) & national (24) & pervasive (16) \\
empty (73) & fuzzy (39) & secure (24) & physical (16) \\
uncomfortable (73) & old (39) & subjective (24) & \\
\hline
\end{tabular}

In the BNC, the noun feeling occurs 6966 times, and there are 674 types of sequences ADJECTIVE feeling; the attributive adjectives modifying feeling occurring at least 10 times are the following: 
Table 4: Adjectives occurring in the sequence ADJECTIVE feeling (BNC)

\begin{tabular}{|l|l|l|l|l|}
\hline strong (112) & widespread (23) & sick (18) & unpleasant (11) & distinct (11) \\
sinking (47) & growing (26) & strangest (9) & public (28) & genuine (10) \\
general (108) & intuitive (10) & sneaking (7) & nationalist (10) & familiar (10) \\
strange (61) & awful (15) & funny (17) & deep (17) & cold (11) \\
bad (67) & ill (24) & terrible (17) & intense (12) & good (29) \\
uneasy (28) & same (55) & eerie (9) & anti-us (5) & local (21) \\
uncomfortable (29) & odd (22) & religious (18) & warm (14) & own (26) \\
instinctive (18) & great (44) & real (27) & nagging (6) & special (12) \\
horrible (22) & personal (30) & vague (12) & dreadful (9) & national (15) \\
nasty (22) & overwhelming (15) & sudden (15) & curious (10) & particular (10) \\
wonderful (26) & anti-American (8) & uncanny (8) & popular (16) & different (10) \\
\hline
\end{tabular}

Not all the occurrences are relevant, since feeling is polysemous, so that some of those sequences have a meaning differing from the meaning under study in this paper ${ }^{18}$, and the figures in brackets are merely illustrative ${ }^{19}$.

Here again, the adjectives fall into several semantic categories:

- Category A: as is the case with emotion, some of the adjectives are connected with intensity: strong, overwhelming, intense:

(12) While I stood there, feeling the hollow emptiness of uselessness, I began to feel something else overcome me, a familiar feeling, the overwhelming feeling of being full of my love for her. (COCA, Eric Kraft, Flying, 2009)

- Category B adjectives deal with the valence of the affect: (amazing), (best), (better), good, great, (incredible), (nice), (positive), wonderful; awful, terrible, horrible:

(13) As I put my clothes in my dresser, I kept expecting him to walk into the room and I had trouble accepting the fact that it was impossible. I missed our weekly phone calls and knowing he was only a few hours away. He'd been so easy to talk to and I'd always felt his unconditional love. It was a terrible feeling to know that there wasn't a soul in the world now who loved me that deeply. (COCA, Diane Chamberlain, The Silent Sister, 2016)

- Category $C$ adjectives are evaluative and are related to the normal or abnormal character of the affect: eerie, funny, odd, (weird):

(14) What with Mrs Clements and the girls also gone for the week, I suppose I was very conscious of the fact that once I departed, Darlington Hall would stand empty for probably the first time this century - perhaps for the first time since the day it was built. It was an odd feeling and perhaps accounts for why I delayed my departure so long, wandering around the house many times over, checking one last time that all was in order. (BNC, Kazuo Ishiguro, The Remains of the Day, 1989)

- Category D adjectives are about the emergence or the evolution of the affect: nagging, growing, sudden: 
(15) I screwed a fresh $\mathrm{CO} 2$ cartridge into my fishing vest. The small bottle held enough pressurized gas to inflate the vest in case of an emergency. Activated by a ripcord, it would float me in case I came loose in the rapids. As I loaded the car, I had this nagging feeling I'd forgotten something. (COCA, Warren C. Easley, Dead Float, 2014)

- Category E adjectives concern the extent of the affect among the population: general, widespread:

(16) At the same time, residents and local politicians demonstrated Friday against the mayor's recent decision to eliminate funding for two schools that would serve Lower Manhattan's growing residential population.

Still, there is a widespread feeling that it is time for change in the plans for downtown. (COCA, Charles V. Bagli, "A Blueprint For Conflict At Ground Zero", New York Times, 2006)

- Category $\mathrm{F}$ adjectives refer to the nature of the experience of the feeling: (creepy), (empty), good, (queasy), sick, (sickening), sinking, uncomfortable, uneasy, warm:

(17) But when it came time and I sat there contemplating the white casket smothered in pink lilies sitting at the base of the altar, I felt a sick feeling rising in my gut. (COCA, Katarina M. Spears, Breakaway, 2015)

(18) Carmen lay awake, certain she was to blame, because she was, as their mother so often said, the ringleader. She had a sick feeling that being mean to the dolls had caused their father's illness. (COCA, Rosaleen Bertolino, "The Doll Family", New England Review, 2017)

(19) It was graduation day, and the strange man standing at the top of the cobblestone stairwell gave me an uneasy feeling. It was like he was waiting on me. With each step I climbed, the feeling turned into a gnawing in my stomach, gripped me a bit more, pulling at my good mood. (COCA, Jason Overstreet, The Strivers' Row Spy, 2017)

(20) Thinking about the girl was like studying a childhood photograph, like reading an old diary entry. It was the way some people looked to their children to understand their own mistakes. Debbie sipped her wine, and $a$ warm feeling spread from her esophagus into her chest and belly. (COCA, Miciah Bay Gault, "Stepping out of the Cow", Southern Review, 2014)

- Category $\mathrm{G}$ adjectives are classifying, such as human or religious:

(21) Both the fervor and the resulting Christian pluralism were keys to much that happened later. The intensity of religious feeling among members of the founding generation has been noted by an earlier essay in these pages [...]. (COCA, M. Stanton Evans, "The Custom of the Country", American Spectator, 2007)

- Finally, category $\mathrm{H}$ adjectives convey an opinion or an ideology (anti-American, anti-US, nationalist):

(22) Washington had to take account of the approach of a British general election - either in 1959 or 1960 . Concern over the dangers of nuclear war and over fall-out from nuclear tests - was adding to the strength of antiAmerican feeling among highly vocal sections of British opinion. (BNC, C. J. Harlow, The Special Relationship: a Political History of Anglo-American Relations since 1945, 1992)

It is noticeable that the role of the adjectives varies with the meaning and the syntax of feeling in each utterance: when feeling admits a prepositional phrase or a clause as a 
complement the adjectives tend to be evaluative or descriptive (15, for instance). Moreover, the sequences ADJECTIVE feeling are compatible with the various meanings of feeling, be it that relating to a sensation (17), an affect (13) or an opinion (16). In (18), for instance, the complement clause that being mean to the dolls had caused their father's illness identifies the cognitive content of the feeling, whereas the adjective sick identifies the nature of the affect.

\subsubsection{Category $F$}

This subsection is about category $\mathrm{F}$ adjectives, characterizing the nature of the feeling: they often seem to be evaluative or descriptive, such as queasy, sick or warm. However, unlike typical evaluative and descriptive adjectives, they cannot be used predicatively:

(17) But when it came time and I sat there contemplating the white casket smothered in pink lilies sitting at the base of the altar, I felt a sick feeling rising in my gut.

(17') ??I felt a feeling rising in my gut. That feeling was sick.

(19) It was graduation day, and the strange man standing at the top of the cobblestone stairwell gave me an uneasy feeling.

(19') ??the strange man standing at the top of the cobblestone stairwell gave me a feeling that was uneasy.

41 The questionable grammaticality of (17') and (19') suggests that those adjectives are to some extent categorizing adjectives in the sense that they refer to a type of affect. Their use sometimes constitutes a hypallage since it is the experiencer himself or herself who is characterized by the adjective:

(17") I felt sick in my gut.

(19") the strange man standing at the top of the cobblestone stairwell made me feel uneasy.

This issue will further be dealt with in Section 4.2.3.

\subsection{Summary}

The adjectives co-occurring with feeling are more varied than those modifying emotion, which, on the one hand, results from the polysemy of feeling, and, on the other hand, from the fact that feeling does not designate the same type of affects as emotion, as the next section aims to demonstrate.

\section{Core affect and emotions}

The analysis of what Barrett [2006: 30-31] names "core affect" offers an interesting insight into the distinction between the nouns emotion and feeling:

my first suggestion to account for the experience of emotion is that something called core affect is the basic building block of emotional life. Core affect has been characterized as the constant stream of transient alterations in an organism's neurophysiological state that represent its immediate relation to the flow of changing events [...].

As the "basic building block of emotional life", core affect is the basis for emotions ${ }^{20}$ : 
Core affect is the ongoing, ever-changing state that is available to be categorized during emotion conceptualization, much like the visible light spectrum is categorized in color perception [...].

Barrett's research leads her to conclude that what she calls "emotions" results from categorization:

the experience of feeling an emotion, or the experience of seeing emotion in another person, occurs when conceptual knowledge about emotion is brought to bear during the act of categorization. The experience of feeling emotion occurs when a person categorizes his internal state. [Barrett 2006b: 27]

Core affect is characterized by its binary value ${ }^{21}$, whereas emotions result from a more complex cognitive treatment and emerge as a consequence of core affect:

First, the act of categorization performs a kind of figure-ground segregation [...] so that the experience of an emotion will pop out as a separate event from the ebb and flow in ongoing core affect [...]. In doing so, people divide ongoing changes in core affect into meaningful experiences. [Barrett 2006: 36]

\section{What Barrett [2006: 35] calls "emotions" are therefore:}

[...] at once affective and conceptual. [...] The idea is that conceptual and affective processing proceed in parallel, with the processing in each limiting, shaping, and constraining the way in which the brain achieves a single coherent "solution" - an instance of experienced emotion that is organized into a coherent interpretation and action plan that suits the particular goals of the individual and constraints of the context. All this occurs in the blink of an eye.

The dichotomy identified by Barrett seems to find an echo in the ways the substantives emotion and feeling function. As we have seen above, emotion is compatible with a restricted range of adjectives denoting mainly strength, and whether the affect is expressed or not. In that sense, emotion refers to an experience that is not semanticized, since it has not yet been given a meaning and results from a basic cognitive analysis. On the other hand, feeling is modified by adjectives that describe the nature of the experience undergone by the human subject; as Barrett highlights, it is the result of an operation of categorization and is both "affective and conceptual". In other words, the noun emotion seems to designate what Barrett names "core affect" and the noun feeling what she calls "emotion".

This hypothesis is backed up by the non-count use of emotion, redolent of "the ongoing, ever-changing" character of core affect, as opposed to the "separate" nature of feeling, which is mainly used as a count noun.

Finally, the "affective and conceptual" nature of what Barrett calls "emotion" is reminiscent of the polysemy of feeling, which can designate affects and opinions, and often mixes those two dimensions, as illustrated by the structure ADJECTIVE feeling of + NP or ADJECTIVE feeling + complement clause. These features of emotion and feeling all suggest that the latter refers to an experience imbued with meaning, whereas the former designates pre-semantic experience.

The object of the next section is to show that these characteristics are connected with the etymology and the morphology of the two nouns. 


\section{Etymology and morphology}

\subsection{Emotion}

50 The OED notes that emotion, borrowed from French, was first used in English at the end of the $16^{\text {th }}$ century to refer to "Political agitation, civil unrest; a public commotion or uprising" (the first recorded example of that meaning 22 dates back to 1562) and "Movement; disturbance, perturbation; an instance of this" (the first example ${ }^{23}$ is from 1594).

Later on, in the $17^{\text {th }}$ century, Thorley [2013: 5] notes that emotion:

was a term whose meaning was in flux. That is to say, while both early senses of the word - 'political unrest' and 'physical movement' - remain in play throughout the period, during that time it is also possible to trace the word's dominant usage as it undergoes a transition from 'movement' to something akin to strong 'feeling or passion'.

He also states that:

the word's ability to mean both 'movement' and 'feeling or passion', senses which the OED now holds to have had almost simultaneous development, should not be surprising given that, in many examples, the humoral fluid responsible for creating the passions is the very thing which is in motion.

Thorley [2013: 15] considers that the next step leading to the contemporary use of the word is exemplified by a phrase coined by Jeremy Taylor, 'the emotions of an unquiet conscience':

Here, we seem to find an account of emotion as movement, but that which is moving is not spirits but conscience, that is, (in OED's definition) 'inward knowledge, consciousness; inmost thought, mind.' In instances of emotion such as this, a stage in the process I have been tracing can be observed: it has moved from its political usage to a physical one, and onward to one in which it is internalised and made to demonstrate the working of human anatomy. After this, I suggest, it is able to elide the anatomical meaning, and become a simple shorthand for mental affections.

To summarize, "emotion during the seventeenth century [...] had taken the early steps of the long evolutionary journey that would distance it from the physical, fixing it more commonly in the mental realm" [Thorley 2013: 15].

The substantive emotion is therefore etymologically and historically connected with the idea of movement and agitation: it first designated an event that leads to a change of situation before stability is reached. There seem to be remnants of that origin in the contemporary use of emotion, as the idea of disturbance, of change in the making is in keeping with the "core affect" postulated by Barrett and with the idea that emotion refers to an affective experience whose cognitive treatment remains to be completed.

\subsection{Feeling}

As we saw in the previous sections, feeling refers to different types of affects, which this section argues is connected with its being derived from the verb feel. 


\subsubsection{Feeling and analysis} cognition, as is the verb feel. Paulin [2003:131] explains that when the verb refers to affects, "nous considérerons qu'il y a une relation d'altérité non stricte de perception de soi par soi-même. Le sujet perçoit ce qui n'est autre chose que lui-même, comme le même et un autre que lui." ${ }^{24}$ The experiencer is therefore split into two entities, the subject of the affect and the observer of that subject. In other words, feel encodes the distance taken by the experiencer from his or her own experience, which allows him or her to give it meaning and to categorize it. This property of feel can be found in the substantive feeling: the categorization involved explains the three semantic dimensions of feel and feeling - perception, affect and cognition -, since affect is here a form of selfperception which involves cognitive categorization. It also accounts for the fact that several semantic components can often be detected in occurrences of feeling.

\subsection{2. -ing}

Feeling is a particular case of -ing derivation; indeed, according to Quirk et al. [1985] the nominal suffix -ing corresponds to the following cases:

[i] noncount concrete aggregates are fairly freely formed, such as tubing, panelling, matting, carpeting, all with reference to the material of which it is made;

[ii] 'activity connected with', as in cricketing, farming, blackberrying. Such nouns, abstract and noncount, are fairly freely made [...] [Quirk et al. 1985: 1548]

concrete count nouns referring to what results from the action of the base, as in building, opening, filling (in tooth); some are obligatory plurals: earnings, savings, shavings. Occasionally the formations are noncount: stuffing, clothing. The abstract count items christening, wedding refer rather to the occasion of the base verb's activity. [Quirk et al. 1985: 1550-1551]

Feeling does not belong to any of these categories: it is generally used as a count noun and therefore deviates from the two groups identified in the first quote; it does not refer to the result of an action or to an event either, and therefore differs from the third group. Although it is a fully-fledged noun - as opposed to a gerund or a gerundial noun - it maintains a strong connection with the inflectional suffix, as it refers to the very actualization of the situation denoted by feel, and it has no other reality than that actualization for the experiencer.

The inflectional prefix nominalizes the verb:

On considère habituellement que le mot en ing devient alors hétérogène, car sans abandonner sa nature sémantique primitive, - il réfère encore à un acte, à un état ou à un devenir, à un "procès", il dit un rapport extralinguistique, selon la définition traditionnelle $\mathrm{du}$ verbe -, il acquiert une fonction syntaxique caractéristique du nom en instanciant dans le cas le plus typique une place d'argument dans une relation prédicative. ${ }^{25}$ [Cotte 1994: 233]

This paper argues that the derivational suffix found in the substantive feeling is anaphoric, like the inflectional suffix, and keeps a connection with an underlying predicative relation. The role of -ing is here both to establish a link with the actualization of a predicative relation and to present the result of that actualization as an autonomous entity, since it is designated by a substantive: 
Grevisse définit le nom comme ce qui «nomme » les êtres et les choses et il ajoute «Tout mot du langage peut devenir un nom dès que l'on considère ontologiquement, en le faisant passer sur le plan de l'être", la notion qu'il exprime » $(1964: 166)$; autrement dit, «nommer » c'est détacher un référent de sa situation d'occurrence et le porter à la transcendance, le rendre atemporel, le prendre en lui-même et pour lui-même. ${ }^{26}$ [Cotte 1994: 240]

The next subsection aims to show that this is why some of the adjectives modifying feeling form hypallages.

\subsubsection{Feeling and hypallage}

As observed in Section 2.3.2, hypallages can be found in the following utterances:

(17) But when it came time and I sat there contemplating the white casket smothered in pink lilies sitting at the base of the altar, I felt a sick feeling rising in my gut.

(17") I felt sick in my gut.

(19) It was graduation day, and the strange man standing at the top of the cobblestone stairwell gave me an uneasy feeling.

(19") the strange man standing at the top of the cobblestone stairwell made me feel uneasy.

As said above, the adjective denotes the nature of the affect experienced. Furthermore, Cotte [1991] observes that the adjective category is related to preconstruction:

L'adjectif, en effet, est une unité du trésor de la langue, qui préexiste en tant que telle à tout discours mais qui, à la différence du nom, ne réfère pas à la chose prise en soi et pour soi comme une réalité autonome et séparée mais qui y réfère indirectement en tant qu'elle est intégrée à un support. De ce fait dire, par exemple :

(8) Et pendant qu'il séchait ce haillon désolé (V. Hugo, Le Mendiant, cité par Morier) c'est montrer, au moment du discours, la désolation déjà intégrée au haillon, c'est décrire le réel sans faire dépendre la relation de l'énonciation et c'est opérer une F.A [ = fausse attribution].

Il n'y a pas de F.A. sans cette préconstruction [...] Ce n'est donc pas seulement l'association notionnelle qui fait le hiatus de la F.A. mais le fait que la relation est objectivée, donnée dans la chose elle-même, présentée comme indépendante de l'énonciateur ${ }^{27}$. [Cotte 1991: 86]

Consequently, the hypallage (what the author calls "fausse attribution") completes the operation consisting in presenting the affect as an autonomous entity, independent from the experiencer. In that sense, the emergence of hypallages is in keeping with the -ing form; the substantive feeling is the result of the situation it is connected with, and the hypallage shows that the feeling cannot be dissociated from the experiencer's state; at the same time, the nominal status of feeling imbues it with an autonomous existence.

Those adjectives highlight the paradoxical nature of what feeling designates: the affect emanates from the experiencer, however, as a noun, feeling separates the affect from a singular experience.

\subsection{Summary}

The etymological and morphological characteristics of emotion and feeling reflect their semantic singularities: the contemporary meaning of emotion as pre-semantic affect echoes its historical connection with the idea of agitation and disturbance; moreover, 
the nominalization of the verb yielding feeling accounts for its polysemy, its denoting semanticized affects and the hypallages it forms.

\section{Emotions and feelings: a few remarks}

65 In their plural form, emotion and feeling do not co-occur with the same adjectives as in the singular.

\subsection{Definitions}

66 The OED offers several definitions specific to the plural feelings ${ }^{28}$ :

1. In plural. A person's emotions or sympathies considered collectively; the emotional susceptibilities or tendencies of a person's character.

He's not a great one for showing his feelings but he was in the most frightful state, I can tell you.

2. Usually in plural. Sympathy or fondness for, or emotional attachment to, a person or thing; (in later use esp.) romantic attraction. Frequently in to have feelings for.

I didn't expect to meet Leo and end up having feelings for him, but I did.

3. With modifying word: an emotion or attitude of the specified type that two or more people or groups feel with respect to each other. Frequently with between. Now sometimes in plural.

The ads... intensified bad feelings between factions of the Democratic Party.

67 The plural occurs when multiple feelings are referred to, either concerning one individual, as in the first definition, or several experiencers (cf. definition 3). More surprisingly, the second definition designates a specific type of affect.

\subsection{Collocations}

\subsubsection{Emotions}

68

Table 5 lists the 73 adjectives occurring more than five times with the plural form emotions in the COCA and Table 6 the 42 adjectives occurring more than three times in the $B N C^{29}$ : 
Table 5: Adjectives occurring more than 5 times in the sequence ADJECTIVE emotions (COCA)

\begin{tabular}{|l|l|l|l|l|}
\hline negative (359) & personal (31) & overwhelming (13) & disturbed (9) & private (7) \\
mixed (194) & real (30) & painful (13) & particular (9) & repressed (7) \\
strong (171) & deep (29) & similar (13) & big (8) & tender (7) \\
positive (168) & certain (28) & specific (13) & nationalist (8) & universal (7) \\
human (154) & complicated (17) & appropriate (12) & corresponding (7) & wild (7) \\
conflicting (132) & true (17) & deepest (12) & darker (7) & anticipated (6) \\
other (83) & unpleasant (17) & volatile (12) & destructive (7) & bittersweet (6) \\
intense (72) & contradictory (16) & difficult (11) & differential (7) & confused (6) \\
moral (66) & high (16) & religious (11) & distinct (7) & dark (6) \\
different (60) & pent-up (16) & conflicted (10) & heated (7) & disturbing (6) \\
basic (48) & social (15) & extreme (10) & natural (7) & great (6) \\
powerful (48) & various (14) & heightened (10) & normal (7) & hard (6) \\
raw (46) & violent (14) & turbulent (10) & old (7) & passionate (6) \\
complex (39) & new (13) & uncomfortable (10) & primary (7) & strange (6) \\
\hline
\end{tabular}

Table 6: Adjectives occurring more than 3 times in the sequence ADJECTIVE emotions (BNC)

\begin{tabular}{|l|l|l|}
\hline conflicting (30) & Fragile (4) & confused (3) \\
mixed (23) & other (16) & intense (3) \\
negative (22) & unruly (3) & raw (3) \\
strong (27) & hidden (4) & such (10) \\
human (26) & positive (6) & extreme (3) \\
own (35) & turbulent (3) & basic (4) \\
pent-up (6) & violent (4) & real (5) \\
deepest (7) & complex (5) & strange (3) \\
uncomfortable (7) & deep (5) & ordinary (3) \\
suppressed (5) & destructive (3) & dark (3) \\
wayward (5) & inner (4) & several (4) \\
tangled (4) & deeper (3) & various (3) \\
contradictory (4) & overwhelming (3) & right (3) \\
different (11) & same (9) & new (5) \\
\hline
\end{tabular}

Some of these adjectives are similar to the adjectives co-occurring with the singular form emotion and some are related to the intensity of the affect (deep, extreme, great, intense, overwhelming, powerful, raw, strong, violent). However, overall, the semantic groups tend to differ widely from those occurring with the singular; only few adjectives are related to whether or not the affect is manifested, and that category is restricted to pent-up and suppressed here. 
70 On the other hand, other sub-groups emerge: the adjectives dark(er), destructive, negative, positive, uncomfortable are related to the actual experience of the affect and to its valence ${ }^{30}$.

71 Finally, several adjectives denote complexity or contradiction: complex, conflicting, contradictory, mixed, turbulent and some of them are among the most frequent adjectives with the form emotions (mixed and conflicting). As observed in Section 3, emotion in the singular tends to appear as a non-count noun, which is obviously not the case in the plural; however, the adjectives referring to complexity suggest that the affects described are lumped together and cannot easily be disentangled:

(23) The men Jeb had sent for supplies were coming in as I left the room and by the time I returned with ice packs, Amber had been hooked up to an IV and fluid was dripping down the line into the vein at her wrist. Her eyes were closed. She was either asleep or almost there so I didn't disturb her. Instead, I handed Jeb the compresses, then sat on the love seat near the bed and watched, helpless.

I was actually grateful for that helplessness. Of the myriad complex emotions that were weighing on me at the moment, helplessness was the easiest to carry. It was the one I knew. (COCA, Laurelin Paige, Last Kiss, 2017)

\subsubsection{Feelings}

Table 7 lists the 70 adjectives occurring more than five times with the plural form emotions in the COCA and Table 8 the 56 adjectives occurring more than five times in the $B N C^{31}$ :

Table 7: Adjectives occurring more than 5 times in the sequence ADJECTIVE feelings (COCA)

\begin{tabular}{|c|c|c|c|c|}
\hline hard (483) & warm (72) & bruised (41) & suicidal (26) & normal (18) \\
\hline strong (462) & inner (70) & general (40) & certain (24) & anti-American (17) \\
\hline negative (397) & different (64) & emotional (39) & conflicted (23) & physical (17) \\
\hline personal (305) & similar (64) & angry (37) & hostile (23) & homosexual (16) \\
\hline positive (275) & ambivalent (57) & powerful (34) & fuzzy (22) & internal (16) \\
\hline mixed (265) & human (57) & religious (34) & painful (22) & nationalist (16) \\
\hline true (215) & deepest (51) & subjective (33) & unresolved (22) & passionate (16) \\
\hline hurt (210) & old (49) & contradictory (31) & guilty (21) & raw (16) \\
\hline bad (201) & other (47) & private (31) & intimate (21) & shared (16) \\
\hline $\operatorname{good}(172)$ & romantic (47) & stronger (31) & patriotic (21) & ambiguous (15) \\
\hline real (95) & tender (47) & complex (30) & deeper (20) & current (15) \\
\hline intense (90) & conflicting (44) & complicated (29) & aggressive (19) & individual (15) \\
\hline deep (86) & bitter (43) & new (28) & initial (19) & moral (15) \\
\hline sexual (73) & innermost (42) & increased (26) & uncomfortable (19) & natural (15) \\
\hline
\end{tabular}


Table 8: Adjectives occurring more than 5 times in the sequence ADJECTIVE feelings (BNC)

\begin{tabular}{|l|l|l|l|}
\hline own (159) & emotional (15) & painful (8) & same (17) \\
mixed (69) & positive (18) & aggressive (8) & private (10) \\
strong (79) & bad (21) & intense (8) & individual (9) \\
personal (68) & deep (17) & hostile (7) & natural (8) \\
true (53) & hurt (10) & powerful (10) & actual (6) \\
negative (36) & human (18) & conflicting (6) & other (20) \\
ambivalent (19) & unconscious (9) & deepest (5) & normal (6) \\
unwanted (18) & deeper (9) & unpleasant (6) & certain (7) \\
real (34) & religious (13) & tender (6) & general (8) \\
sexual (24) & innermost (6) & associated (6) & different (8) \\
hard (27) & unproductive (6) & loving (5) & old (7) \\
subjective (14) & uncomfortable (8) & similar (11) & national (5) \\
inner (17) & violent (9) & injured (5) & good (7) \\
finer (11) & confused (8) & vague (5) & new (8) \\
\hline
\end{tabular}

Among the adjectives common to the two lists, some of the semantic groups that can be identified are similar to those found with the singular feeling: adjectives related to intensity (deep, intense, strong), valence (good, negative, painful, positive, uncomfortable), authenticity (real, true) and classifying adjectives (emotional, religious, sexual). Adjectives occurring with the plural feelings differ from those forming collocations with the singular on three accounts: as is the case with emotions, one subgroup is related to heterogeneity (ambivalent, conflicting, mixed); one subgroup is specific: bad feelings, hard feelings and tender feelings refer to social affects; finally, one can also identify adjectives referring to one individual's affects (personal, private and subjective):

(24) It was their mother who'd been the glue that kept them connected, Frank and Casey. Her constant smile and teasing words lightened the years of bad feelings between brothers who'd been born more than a decade apart. Now, though, they had less than nothing in common. (COCA, Suzanne Brockmann, Headed for Trouble, 2013)

Bad feelings designates affects caused by other people's behaviour which are in that sense social affects. Social affects are overrepresented with the plural feelings whereas the adjectives found with feeling in the singular and connected with the nature of the experience (sick, sinking, etc.) are not common with the plural ${ }^{32}$. Moreover, phrases such as ambivalent feelings, conflicting feelings or mixed feelings often designate opinions rather than pure affects:

(25) But a public document would almost certainly see wide distribution, finding its way onto the Internet, for example, Mr. Jester said. [...] Then, he added, "it can be reviewed by anyone in the world."

Because the findings could likely be applied to a wide range of projects, however, many wonder where the line between military security and public safety should be drawn.

"I have conflicting feelings," said John Durrant, executive director of the Structural Engineering Institute of the American Society of Civil Engineers. 
"We believe the findings would be of benefit to the profession. On the other hand, we are very sensitive to the need for national security." (COCA, James Glanz, "Lessons Drawn From Attack On Pentagon May Stay Secret", New York Times, 2002) relation based on the verb feel; in its plural form, feeling is more clearly grounded in the paradigms of prototypical nouns, and is therefore at a further remove from the verb and the predicative relation, so that the referent is not envisaged as the direct product of the experiencer's affective and cognitive activity. This seems to go hand in hand with the fact that the plural, unlike the singular, does not focus on the actual experience of the affect, but either on social entities circulating between individuals or on opinions, encompassing several components.

In that sense, the plural has two different effects on the semantics of emotion and feeling: with emotions, it is connected with confusion, whereas with feelings, it has to do with the addition of separate entities.

\section{Conclusion}

Although emotion and feeling both refer to affects and are considered to be synonymous in some of their uses, a closer analysis of the collocations they form with adjectives shows that they refer to different kinds of affects, as emotion denotes affective experiences that have not been categorized, whereas feeling refers to affects that have undergone a more elaborate cognitive treatment. Those characteristics are correlated with the etymology and morphology of those words, but also with the experience of affect as described by cognitive neuroscience. Finally, the plural forms emotions and feelings form specific collocations, which reflects a social and intellectual conception of affects, further removed from individual experience.

\section{BIBLIOGRAPHY}

BARRETT Lisa F., 2006, "Solving the Emotion Paradox: Categorization and the Experience of Emotion", Personality and Social Psychology Review, Vol. 10, No. 1, 20-46.

СотTE Pierre, 1994, « Le paradoxe du nom verbal en anglais contemporain », in BASSET Louis \& PerenNeC Marcel (Eds.), Les Classes de mots, Traditions et perspectives, Lyon : Presses universitaires de Lyon, 233-265.

COTTE Pierre, 1991, «L'hypallage ou la fausse attribution », Théorie Littérature et enseignement TLE $\mathrm{n}^{\circ}$ 9, Figuralité et cognition, Saint-Denis : Presses Universitaires de Vincennes, 179-195.

DAMASIO Antonio, 1994, Descartes' Error: Emotion, Reason, and the Human Brain, Putnam Publishing New York: Avon Books.

Lexis, 15 | 2020 
DAVIES Mark, 2008-, The Corpus of Contemporary American English: 560 million words, 1990-present, available at http://corpus.byu.edu/coca/

KöVECSES Zoltán, 2000, Metaphor and Emotion: Language, Culture, and Body in Human Feeling, Cambridge: Cambridge University Press.

HILGERT Emilia, 2018, « Le nom émotion est-il un hyperonyme ? », in KLEIBER Georges, HILGERT Emilia \& PALMA Silvia (Eds.), Res per nomen VI - Les catégories abstraites et la référence, Reims : Éditions et presses universitaires de Reims, 79-102.

LANGACKER Ronald, 1991, Concept, Image, and Symbol, The Cognitive Basis of Grammar, Berlin/New York: Mouton de Gruyter.

Oxford English Dictionary, available at http://www.oed.com

PAULIN Catherine, 2003, «Polysémie et complémentation verbale $:$ le verbe feel dans tous ses états ", in DELMAS Claude \& Roux Louis (Eds.), Correct, Incorrect en linguistique anglaise C.I.E.R.E.C, Travaux 113, Publications de l'Université de Saint-Étienne Jean Monnet, 129-155.

QUIRK Randolph, GREENBAUM Sidney, LEECH Geoffrey \& SVARTVIK Jan (Eds.), A Comprehensive grammar of the English language, London, New York: Longman.

ROMERO clara, 2004, «Les adjectifs intensifs ", in JACQUES François, L'adjectif en français et à travers les langues, Caen : Presses universitaires de Caen, 449-462.

THORLEY David, 2013, "Towards a History of emotion, 1562-1660", in The Seventeenth Century, vol. $28, \mathrm{n}^{\circ} 1,3-19$.

WIERZBICKA Anna, 1999, Emotions across languages and cultures: Diversity and Universals, Cambridge: Cambridge University Press.

\section{NOTES}

1. Emphasis added.

2. Each of the definitions is followed by one of the examples quoted in the OED.

3. "Seventy years ago the founder of behaviourism John Waston proposed the following definition (quoted in Plutchik 1994: 3): “An emotion is an hereditary 'pattern-reaction' involving profound changes of the bodily mechanisms as a whole, but particularly of the visceral and glandular systems"." (Wierzbicka [1999: 1])

4. "There seems to be a sort of polysemy between language for specific purposes - where the noun émotion is generic and encompasses a set of various types of emotions, such as peur, tristesse, colère, etc. which are subtypes of émotions - and common parlance, where the noun émotion désignates a specific manifestation, and is on the same lexical level as peur, colère, tristesse, etc." (my translation)

5. "nouns are synthetic and hide the complexity of their referent", whereas adjectives are "analytical and detail the contingent qualities that nouns neglect or contain in their synthetic definition". (my translation)

6. "A noun is a lexical unit that synthesizes the structural features identifying the referent as a stable, preconstructed category, whereas one or several adjectives break it into its properties, whether contingent or not, as the speaker uncovers them if he or she wants to. Adjectives separate what nouns conceal and they also express an evaluation of the referent." (my translation)

7. The figures in brackets correspond to the number of occurrences of each sequence. 
8. The COCA contains over 560 million words, and the BNC around 100 million words.

9. The adjectives in brackets are those that appear only in one of the two tables.

10. In this example as in the others, the emphasis is mine.

11. "the role of intensity adjectives is to place the occurrence at the top of the scale defining the noun. Énorme dans énorme envie or terrible in chaleur terrible do not so much characterize envie or chaleur (as would envie bizarre or chaleur humide) or categorize them (the NP envies énormes does not designate a type of envies, unlike envie de voyage) as indicate that the referent is placed at the top of the scale "envie" or "chaleur"." (my translation)

12. She adds that whether the noun modified is a priori gradable or not is immaterial: "Il en est de même pour un prédicat a priori non gradable [...] : disant de vraies vacances, on ne parle pas d'une qualité des vacances (comme ce serait le cas avec longues, chères), on ne parle pas de tel type de vacances (d'hiver, touristiques), mais on dit que les propriétés qui constituent le sens de vacances sont réunies, ou intensifiées." (Romero [2004: 451]) ("The same holds for adjectives that would appear non-gradable [...]: the NP de vraies vacances does not refer to a property of the holidays (as would be the case with longues or chères), or to a kind of holidays (d'hiver, touristiques), but indicates that the properties that make up the essence of holidays are brought together or intensified"). (my translation)

13. "the distinction between the two types of phrases is not always clear-cut since the same adjectives can be used as intensity adjectives or intensifying descriptive adjectives. Thus, between the descriptive eau bouillante and the intensity adjectives énorme and extrême in énorme envie and extrême bonté (where the adjectives are merely intensity adjectives), with échec cuisant, banalite consternante, amour passionnel there is both intensification (something that is said to be "d'une banalité consternante" is "d'une grande banalité" or "très banal") and characterization (consternant = "qui est propre à consterner", despite the possible hyperbole). (my translation)

14. "For example, haut is a direct intensity adjective in haut intérêt because no interpretative calculation is required from the qualitative meaning of haut to place the occurrence at the top of the scale "intérêt" (that is, to interpret the NP as meaning "très intéressant")".

15. "Intensity adjectives having a describing component are indirectly intensive; for example, to interpret banalité consternante, an interpretative calculation such as "Only what is very banal can arouse consternation, therefore this is very banal" is necessary.

16. Since "the classical Latin èmōt-" is "the past participial stem of èmovere to remove, expel, to banish from the mind, to shift, displace" (OED).

17. Its "primary domain" being "that in which different instantiations of the category can occur and be identified" (Langacker [1991: 69]).

18. The sequence warm feeling, for instance, is relevant here, but some occurrences are not, as in the following example: "The restaurant has a warm feeling, but other than two murals of masked revelers near the bar, wood and copper trim, and white, teardrop-shaped lamps jutting from pale yellow walls, the crowd is the decor." (COCA, Maria Cianci, "This Spot By Any Name Would Taste as Sweet", San Francisco Chronicle, 1995)

19. Although the majority of the sequences are relevant to this study, some are not; giving the exact number of occurrences requires a systematic manual analysis of each of the utterances, which is beyond the scope of this paper.

20. Barrett's technical use of the noun emotion differs from the use of the word in common parlance.

21. "This form of affective responding is "core" because it is influenced by a very simple form of meaning analysis - whether stimuli or events are helpful or harmful, rewarding or threatening for a given person at a given point in time and whether an active behavioral response is required." (Barrett [2006: 31])

22. "The great tumultes and emotiones that were in Fraunce betwene the king and the nobilitie." 
23. "Such were [...] the terrible expeditions of the Tartarians, [...] thorough the great emotion [Fr. emotion] and mutation of humaine things."

24. "I shall consider that a relation of non-strict alterity underlies self-perception; the experiencer perceives himself or herself as both himself or herself and someone else." (my translation)

25. "One generally considers that the word ending in -ing becomes heterogenous, for while keeping its original semantic nature - it still refers to an act, a state or a change, i.e. to a situation, and expresses an extralinguistic relation, in accordance with the traditional definition of the verb - it also fulfils the syntactic function of a noun since it is prototypically used as an argument in a predicative relation."

26. "Grevisse defines the noun as that which "names" beings and things, and adds, "Any word can become a noun as soon as one considers the notion it expresses from an ontological point of view, at the level of "what is", [1964: 166]; in other words, "to name" is to detach a referent from the situation where it occurs, and to bring it to transcendence, to make it timeless, to consider it in and for itself."

27. "An adjective is a lexical unit which, as such, precedes any discourse but which, unlike a noun, does not refer to an entity taken in and for itself as an autonomous and separate reality; on the contrary, it refers to it indirectly as being integrated into a substrate. In this way, saying: (8) Et pendant qu'il séchait ce haillon désolé (V. Hugo, Le Mendiant, quoted by Morier) is tantamount to showing the "desolation" as already integrated into the rag at the time of utterance, the "false attribution" (F.A.) boils down to describing the real without making the relation depend on the utterance.

There is no F.A. without preconstruction [...] The notional association is therefore not the only element that creates the hiatus in the F.A., the fact that the relation is objectified, given in the thing itself, presented as independent of the enunciator, must also be factored in".

28. Each of the definitions is followed by one of the examples quoted in the OED.

29. There are 13547 occurrences of the plural emotions in the COCA and 1851 in the BNC.

30. These adjectives are often classifying adjectives here, and emotions corresponds to the hypernym identified by Hilgert (2018) in scientific use: among the 359 occurrences of negative emotions in the COCA, 235 come from academic sources (65\%).

31. There are 27312 occurrences of the substantive feelings in the COCA and 5136 in the BNC.

32. There are, for instance, only 2 occurrences of sick feelings (vs. 149 of sick feeling), 1 occurrence of queasy feelings (vs. 47 of queasy feeling) and no occurrence of ?sinking feelings (vs. 247 occurrences of sinking feeling) in the COCA.

\section{ABSTRACTS}

This paper analyzes the adjectives modifying the substantives emotion and feeling in contemporary American and British English. It argues that although the two nouns refer to affects and are treated as synonyms in dictionary definitions, they are not semantic equivalents. The study of their collocations with adjectives shows that emotion refers to pre-semantic experience, whereas feeling designates affects that have been the object of a more elaborate cognitive treatment. This paper also aims to show that the semantic characteristics of the two substantives reflect their morphology and their historical evolution. 
Cette contribution porte sur les adjectifs modifiant les noms emotion and feeling en anglais britannique et américain. Nous cherchons à démontrer que bien que les deux noms renvoient aux affects et qu'ils soient souvent présentés comme synonymes, ce ne sont pas des équivalents sémantiques. L'étude des collocations qu'ils forment avec les adjectifs suggère que emotion renvoie à une expérience pré-sémantique, alors que feeling désigne des affects qui ont fait l'objet d'un traitement cognitif plus élaboré. Cette contribution montre également que les caractéristiques sémantiques des deux substantifs reflètent leur morphologie et leur évolution historique.

\section{INDEX}

Keywords: feeling, emotion, expression of affects, collocations, adjectives, lexical semantics Mots-clés: feeling, emotion, expression des affects, collocations, adjectifs, sémantique lexicale

\section{AUTHOR}

\section{STÉPHANIE BÉLIGON}

Sorbonne Université - CeLiSo EA 7332

stephanie.beligon@sorbonne-universite.fr 